\section{Plants condemned as pesticides}

SIR - Meredith Wadman relates only part of the controversy over a new US Environmental Protection Agency (EPA) policy (Nature 382, 485; 1996). The EPA has in its regulatory crosshairs a promising new area of biotechnology - solely because it is biotechnology. The agency would regulate garden and crop plants as though they were pesticides. Case-by-case regulatory review would be required only when these familiar plants are genetically modified using recombinant-DNA methods to enhance their pest-resistance. Under the new EPA policy, biotechnology-improved varieties of corn, cotton, marigolds and so on are "pesticidal plants". They would not only be regulated more stringently than other plants but also more stringently than chemicals similar to DDT or sarin. US pesticide regulations exempt small-scale field trials (less than 10 acres) of pesticides - whether chemicals or organisms - but this research exemption does not apply to rDNA-manipulated plants. Moreover, the regulations would require rDNA-improved plants to be labelled as "pesticides".

Eleven scientific societies representing more than 80,000 biologists and food professionals published a comprehensive report condemning the EPA's proposal. The report emphasizes that the safety of a new substance synthesized by a plant depends on the biological actions of the substance and where it is expressed in the plant, rather than the fact that it is intended to protect against a plant pest, or on the use of certain genetic techniques.

The report warns that the EPA policy would have negative consequences, including an increased regulatory burden on research and development of pest-resistant crop varieties, the growth of bureaucracy, sustained need for chemical pesticides and competitive disadvantage to those using the new biotechnology.

Wadman points out that the major US industry trade association - the Biotechnology Industry Organization (BIO) - has joined anti-biotechnology groups such as the Environmental Defense Fund "in opposing such conclusions”. In fact, BIO and Monsanto, a company that dominates the association, have not only continued to support EPA's policy in the face of incontrovertible scientific and economic arguments against it, but have actually tried to persuade some of the societies to disavow the report. Alan Goldhammer of BIO and Monsanto's chief Washington lobbyist, Chester Dickerson, have put pressure on representatives of the agronomy, crop science, microbiology, food technology and weed science societies that collaborated on the report.

The EPA policy creates new barriers for smaller, cash-strapped companies. It could virtually extinguish university research on the nature of pest-plant interactions, which is essential for developing alternatives to agricultural chemicals. The large companies that control BIO's positions on agricultural issues are among the world's largest producers of agricultural chemicals Monsanto's sales of crop- and lawn-protection products in 1995 were $\$ 2.47$ billion, for example. These companies therefore have a vested interest in slowing the development of competing, potentially superior products.

At a fundamental level, this collusive, anti-competitive behaviour corrupts one of the principles of the free market - that entities are effectively free to enter into and carry on business transactions. The cynical EPA/BIO/Monsanto strategy makes losers of the research community, entrepreneurial biotechnology companies and consumers.

\section{Henry I. Miller}

Hoover Institution \& Institute

for International Studies,

Stanford University,

Stanford, California 94305-6010, USA

e-mail: miller@hoover.stanford.edu

\section{Did the Romans exploit uranium?}

SIR - In my recent book Uranium Glass, I discussed some Roman mosaic glass of the first century $A D$ that was excavated early in this century near Naples by the Oxford archaeologist R. T. Gunther, who reported that some of its tesserae were made from uranium glass.

Fission-track dating experiments conducted in the United States and Germany showed them to be no older than the beginning of this century. Moreover, US and German teams scanned the site with a radiation detector, but failed to find anything of interest. Doubts were consequently expressed as to whether the Romans really had exploited uranium; such a view appeared in the review of my book (in Nature 379, 34; 1996).

There are, however, good reasons for believing that the Romans probably did exploit uranium. Gunther found a uraniumoxide content of $1.25 \%$ by means of chemical analysis (most Roman glass contains only $0.0005 \%$ ), and he tried to replicate the glass using these results, both with and without added uranium. There were now three kinds of glass: the original Roman glass, the replicated uranium glass and the replicated non-uranium glass.

In 1948, Earle R. Caley reviewed Gunther's report and concluded that the uranium content ought to have been shown as $1.5 \%$ rather than $1.25 \%$. In 1963 , Franz Kirchheimer analysed specimens of the mosaic glass in Oxford and observed a uranium oxide content of $1.6 \%$, a value close to Caley's $1.5 \%$. His analysis also indicated a lead content of about $1 \%$, about which Gunther was silent. If Kirchheimer's experiments had involved only the replicated uranium glass specimens, he would not have discovered a uranium oxide content significantly larger than $1.25 \%$ (as he did), or such an appreciable content of lead. These facts strongly suggest the existence of Roman uranium glass.

The reasons for doubts are not all that strong either. The age of the specimens (less than 100 years) was probably obtained because they had once been melted. Any glass once heated shows only the age after the heating. The unsuccessful surveys in Naples merely suggest that the mosaic glass was unusual for the Roman period.

In 1977, Kirchheimer wrote a detailed case for accepting the existence of Roman uranium glass. He emphasized the significant lead content of a specimen preserved in a test-tube labelled "Oxford Roman glass with Uranium". Although he was aware of the critical arguments, Kirchheimer stood by the existence of Roman uranium glass.

\section{Ken Tomabechi}

4-15-14, Nakahara,

Mitaka-shi,

Tokyo 181, Japan

\section{Dousing the flame}

SIR - In recent years, the Philip Morris Prize for Scientific and Technological Research has been advertised in leading Italian newspapers, and three government bodies have given it their patronage - the National Research Council (CNR), the Ministry of University and Research and the Italian Board of Energy.

During the same period, advertising by tobacco companies has evolved from showing an image of satisfied smokers to highlighting the association of tobacco with positive social values. In Western countries, scientific research is perceived as one of the foundations of welfare; it is therefore potentially rewarding for the Philip Morris Company to link tobacco with such values.

But scientific research should not be associated with smoking, the leading cause of ill-health and death in the Western world. The three government departments concerned should dissociate themselves from any future Philip Morris initiatives.

\section{Paolo Crosignani}

Franco Berrino

Franco Rilke

Istituto Nazionale per lo Studio

e la Cura dei Tumori,

Via Venezian, 1,

I-20133 Milano, Italy 